\title{
Morphology and reproduction of Predaea feldmannii Børgesen (Nemastomataceae, Rhodophyta), an uncommon species from Brazil
}

\author{
SILVIA M.P.B. GUIMARÃES ${ }^{1,3}$ and PAULO A. HORTA²
}

(received: October 16, 2003; accepted: April 8, 2004)

\begin{abstract}
Morphology and reproduction of Predaea feldmannii Børgesen (Nemastomataceae, Rhodophyta), an uncommon species from Brazil). The coast of Espirito Santo State is located in a biogeographic transition zone presenting high diversity. A renewed interest in this region occurred in the 1990s, resulting in various new records and new species descriptions added to the Brazilian marine flora. The study of the infralitoral of this region is just beginning, and a detailed exploration with use of Scuba diving is revealing a flora containing many little-known taxa, particularly of red algae. As a first result, Predaea feldmannii Børgesen is being described for the Brazilian coast. The occurrence of the genus Predaea in Brazil has been considered with restriction since representatives of this genus had been referred only once by Howe \& Taylor in 1931, being first considered as Platoma. The occurrence of Predaea in Brazil is now confirmed, and its vegetative and reproductive structures are described in detail. Predaea feldmannii can be recognized by having gonimoblast initial formed on a bulge of the connecting filament, cortical filaments of nearly equal lengths, lack of gland cells, dense clusters of nutritive cells borne only on cells immediatelly contiguous to the auxiliary cell, and a three-celled carpogonial branch.
\end{abstract}

Key words - morphology, Nemastomataceae, Predaea, Rhodophyta, taxonomy

RESUMO - (Morfologia e reprodução de Predaea feldmannii Børgesen (Nemastomataceae, Rhodophyta), uma espécie incomum no Brasil). O litoral do Estado do Espírito Santo está localizado em uma zona de transição biogeográfica apresentando alta diversidade biológica. O interesse nesta região foi renovado a partir de 1990, com a publicação de várias adições e descrições de espécies novas para a flora marinha brasileira. O estudo do infralitoral desta região está agora se iniciando e uma exploração detalhada através do emprego de mergulho autônomo está revelando uma flora com muitos táxons pouco conhecidos, particularmente de rodofíceas. Como resultado inicial, Predaea feldmannii Børgesen está sendo referida, pela primeira vez, para a costa brasileira. A ocorrência do gênero Predaea no Brasil tem sido considerada com certa restrição, pois representantes do mesmo foram referidos somente uma vez, por Howe \& Taylor em 1931, tendo sido inicialmente atribuídos ao gênero Platoma. A ocorrência de Predaea no Brasil está sendo agora confirmada e as estruturas vegetativas e reprodutivas estão sendo descritas com detalhes. Predaea feldmannii é caracterizada por apresentar iniciais de gonimoblastos formadas a partir de uma dilatação do filamento conectivo, filamentos corticais aproximadamente do mesmo tamanho, ausência de células glandulares, aglomerações densas de células nutritivas formadas somente a partir de células contíguas à célula auxiliar e ramos carpogoniais com 3 células.

Palavras-chave - morfologia, Nemastomataceae, Predaea, Rhodophyta, taxonomia

\section{Introduction}

Espírito Santo State is located in a biogeographic transition zone (Horta et al. 2001) presenting high diversity. A renewed interest in the algae of this region occurred from the 1990s, resulting in various new records and new species descriptions (for a revision see Guimarães 2003). More than three hundred species of Rhodophyta have now been recorded mainly in the intertidal region, and this number represents an important

1. Instituto de Botânica, Seção de Ficologia, Av. Miguel Estéfano 3687, 04301-012 São Paulo, SP, Brazil.

2. Universidade Federal da Paraíba, Centro de Ciências Exatas e da Natureza, Departamento de Sistemática e Ecologia, Cidade Universitária, Campus I, 58059-900 João Pessoa, PB, Brazil. mark to reach a better understanding of the floristic composition for any Brazilian region. By observation of the drift material reaching the beaches of Espírito Santo, the infralitoral is also expected to present a diverse and abundant algal assemblage. However, Brazilian subtidal seaweeds are poorly known, and only a few studies based on dredging as the sampling method have included material of the Espírito Santo region (Joly 1950, Joly \& Yoneshigue-Braga 1966, Joly \& Oliveira 1967, Oliveira 1976, Cordeiro-Marino \& Guimarães 1981). More recently, a detailed exploration of the subtidal Brazilian coast, using SCUBA dive techniques, has allowed several additions to the algal flora of the southwestern Atlantic (Horta \& Oliveira 2000, 2001). A study that now is being carried out in Espírito Santo, is revealing an extensive flora containing many littleknown taxa, particularly of red algae. As a first result 
Predaea feldmannii $\mathrm{B} \emptyset$ rgesen is here reported for the first time for the Brazilian coast.

The genus Predaea (Nemastomataceae) is mainly tropical and subtropical occurring in the eastern and western hemispheres and consists of 14 species that are distinguished from one another by the habit and anatomical features. The genus is well represented in Australia with seven described species. Three species, Predaea laciniosa Kraft, $P$. weldii Kraft \& I.A. Abbott and $P$. feldmannii appear to be more geographically widespread (Saunders \& Kraft 2002).

Based on morphological as well as on molecular evidence, Saunders \& Kraft (2002) proposed to resurrect the order Nemastomatales Kylin sensu G.W. Saunders \& Kraft, to accommodate two families, the Nemastomataceae and the Schizymeniaceae. Members of the Nemastomatales are thought to represent a primitive level of vegetative and reproductive organization within the order Gigartinales. The family Nemastomataceae presently includes the genera Adelophycus Kraft in Womersley \& Kraft, Itonoa Masuda \& Guiry, Nemastoma J. Agardh and Predaea G. De Toni. Thalli of Predaea are mucilaginous and composed of pseudodichotomously branched cortical filaments and a lax medulla lacking secondary pitconnections between adjacent cells. Rhizoidal filaments are borne on cells of the inner cortex. The genus is non procarpic, and the auxiliary cell branch has clusters of nutritive cells. Connecting filaments arise directly from the fertilized carpogonium and branch between the filaments of cortex and medulla fusing with auxiliary cells. Gonimoblasts arise outwardly or laterally. Tetrasporophytes are unknown in the field, but the life history has been demonstrated in culture to consist of an alternation of heteromorphic generations. The tetrasporophytes are represented by microscopic crusts or acrochaetioid filaments that produce zonate (Millar \& Guiry 1989) or cruciate (Lemus \& Ganesan 1977) tetrasporangia.

Up to now Predaea masonii (Setch. \& N.L. Gardn.) G. De Toni was the single taxon of the genus described from Brazil, occurring in Cabo Frio, Rio de Janeiro (Oliveira 1977). This paper provides a detailed taxonomical study of P. feldmannii and describes for the first time its occurrence on the Brazilian coast.

\section{Material and methods}

Specimens were collected in the subtidal through Scuba diving at 6-10 meters depth, in Santa Cruz (19 58.5' $\mathrm{S}$ and $\left.40^{\circ} 07^{\prime} \mathrm{W}\right)$, Aracruz County, and at 6-7 meters depth, near
Ilha do Francês $\left(20^{\circ} 55^{\prime} \mathrm{S}\right.$ and $\left.40^{\circ} 45^{\prime} \mathrm{W}\right)$, Itapemirim County, Espírito Santo State. In the field, the material was preserved in $4 \%$ formalin/seawater. Slides were made by mounting blade fragments in a solution of aniline blue $1 \%$ plus $\mathrm{HCl} 1 \mathrm{~N}$. Photographs were taken using Olympus $\mathrm{BH}-2$ microscope and Olympus C35AD camera. Drawings were made with the aid of a Zeiss camera lucida. Vouchers are housed in the Herbarium of the Instituto de Botânica São Paulo, Brazil (SP355786, SP365540).

\section{Results}

\section{Predaea feldmannii Børgesen}

Plants flattened, foliose, variously lobed and deeply incised (figure 1), to $4 \mathrm{~cm}$ in length, each lobe with $0.5-2 \mathrm{~cm}$ in breadth, narrowing to a short stalk $1-2 \mathrm{~mm}$ in width, and a slighty expanded basal pad. Texture gelatinous, color rose-red. Fronds multiaxial, $500 \mu \mathrm{m}$ in thickness, medulla with slender filaments $2-3 \mu \mathrm{m}$ in diameter and rhizoids derived from cortical and subcortical cells. Cortex 100-130 $\mu \mathrm{m}$ and 5-7 cell layers in thickness, composed of dense fascicles of filaments subdichotomous branched, the cells of which are cylindrical, $8-16 \mu \mathrm{m}$ in length and $1.5-4 \mu \mathrm{m}$ in diameter, and progressively more deeply pigmented outwards (figure 2). Cortical fascicles approximatelly of equal length. Outer cortical cells cylindrical; some surface cells with vegetative hairs. Vesicular cells absent.

Specimens monoecious - Spermatangia sparsely scattered, on terminal mother cells each bearing one or two spermatangia 2-3 $\mu \mathrm{m}$ diameter (figure 3 ). Threecelled carpogonial branches borne laterally on inner cortical supporting cells (figure 4). Basal cell of the carpogonial branch ampulliform, $10-12 \mu \mathrm{m}$ length, second cell sphaerical, 3-5 $\mu \mathrm{m}$ diameter and carpogonium conical-elongated, 5-7 $\mu \mathrm{m}$ length projecting into the trichogyne.

Auxiliary cell intercallary in cortical filaments. Auxiliary cell subsphaerical, 12-16 $\mu \mathrm{m}$. The cells immediatelly proximal and distal to the auxiliary cell bearing from one to three lateral branched nutritive filaments 5-8 cells in length (figures 5, 6). After presumed fertilization, the carpogonium enlarges and cuts up to three septate connecting filaments (figure 7) that branch between the filaments of the cortex and medulla and fuse with auxiliary cells (figures 8,9 ). The connecting filament produces a prominent lateral bulge adjacent to its site of fusion to the auxiliary cell (figures 10, 11). Gonimoblasts are cut off from the lateral bulge of the connecting filament (figures 12, 13, 14). Nutritive cells enlarge forming clusters that often surpass the young 
gonimoblast in size. After contacting the auxiliary cell, the connecting filaments continue to ramify through the thallus contacting other auxiliary cells. The gonimoblast initial divides (figure 14), and its derivatives form a chain composed of four to six cells directed laterally or arched (figure 15). Longitudinal and oblique divisions result in a compact mass of carposporangia (figure 16). Only young carposporophyte were observed; mature ones were not found. Tetrasporophytes unknown.

Habitat: In Santa Cruz plants were growing on a coralligenous reef built by a species of the genus Mesophyllum. The specimens of Predaea were observed on the top of the reef formation, in depths that varied from 6 to 10 meters. The associated community
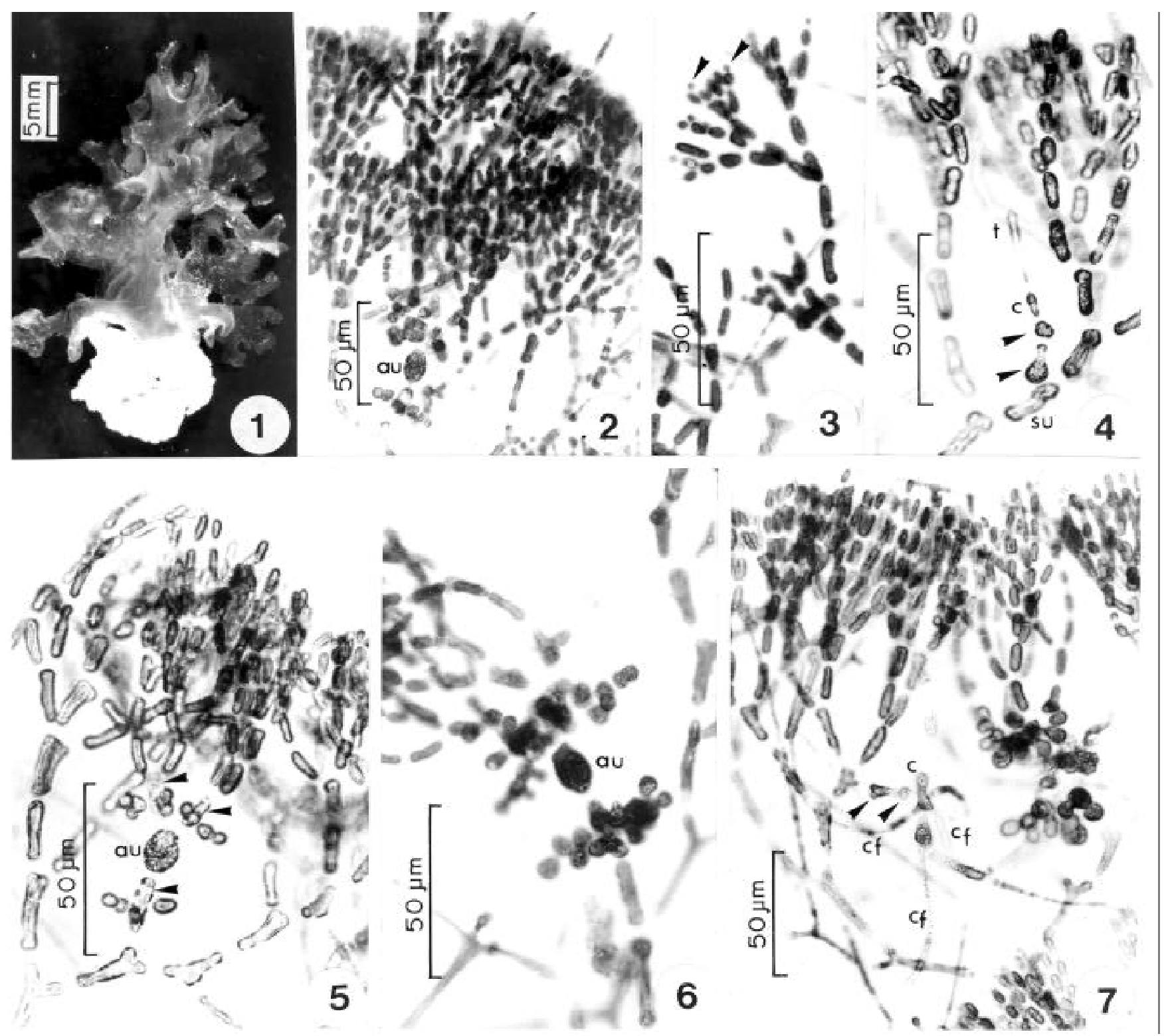

Figures 1-7. Predaea feldmannii. 1. Habit of liquid-preserved specimen. 2. Cortical fascicle of filaments and an intercalary auxiliary cell (au) with associated nutritive filaments. 3. Spermatangia (arrowheads) terminating outer cortical mother cells. 4. Three celled carpogonial branch borne on an inner cortical supporting cell ( $\mathrm{su}$ ); $\mathrm{c}=$ carpogonium, $\mathrm{t}=$ trichogyne. The arrowheads show the first and second cells of the carpogonial branch. 5. A young auxiliary cell branch and the three contiguous cells (arrowheads) each bearing chains of nutritive cells; au = auxiliary cell. 6 . A mature auxiliary cell branch with branched chains of nutritive cells; au = auxiliary cell. 7. A presumed fertilized carpogonium (c) that has cut off three connecting filaments (cf). The arrowheads show the first and second cells of the carpogonial branch. 
was characterized by an abundance of Calliblepharis occidentalis A.B. Joly \& Yam.-Tomita (Gigartinales, Rhodophyta) and Rhipiliopsis stri (Earle \& Young) Farghaly \& Denizot (Bryopsidales, Chlorophyta), besides being also dominated by the presence of a turf of filamentous red algae. In Itapemirim the specimens were observed growing on a rhodolith bed and the associated community was characterized by an abundance of Dictyopteris jolyana E.C. Oliveira \& Furtado, Halymenia brasiliana S.M. Guim. \& M.T. Fujii and H. floresii (Clemente y Rubio) C. Agardh.

Specimens examined: BRAZIL: Espírito SANTO: Aracruz County, Santa Cruz, $19^{\circ} 58.5^{\prime} \mathrm{S}$ and $40^{\circ} 07^{\prime} \mathrm{W}$, 6-10 m depth, 25-I-2001, P.A. Horta s.n. (SP355786); Itapemirim County, near Ilha do Francês, $20^{\circ} 55^{\prime} \mathrm{S}$ and $40^{\circ}$ 45' W, 6-7 m depth, 3-III-2004, G.M. Amado Filho \& M.B.B. Barreto s.n. (SP365540).
Type locality: Atlantic Ocean, St Helena Island.

Distribution: Atlantic Ocean: North Carolina, Georgia, Florida, Caribbean, Brazil, Ghana, St Helena Island.

\section{Discussion}

The presently known species of Predaea on the western Atlantic are a matter of controversy. Predaea feldmannii and P. masonii are reported from the deep waters of North Carolina (Schneider \& Searles 1975). Predaea feldmannii, P. weldii Kraft \& I.A. Abbott, and $P$. goffiana D.L. Ballant., Ruiz \& Aponte are recorded from the Caribbean Sea (Ballantine \& Wynne 1986, Ballantine \& Aponte 1997, Ballantine et al. 2002). Lemus \& Ganesan (1977) reported two species from Venezuela, $P$. feldmannii and $P$. pusilla (Berthold)

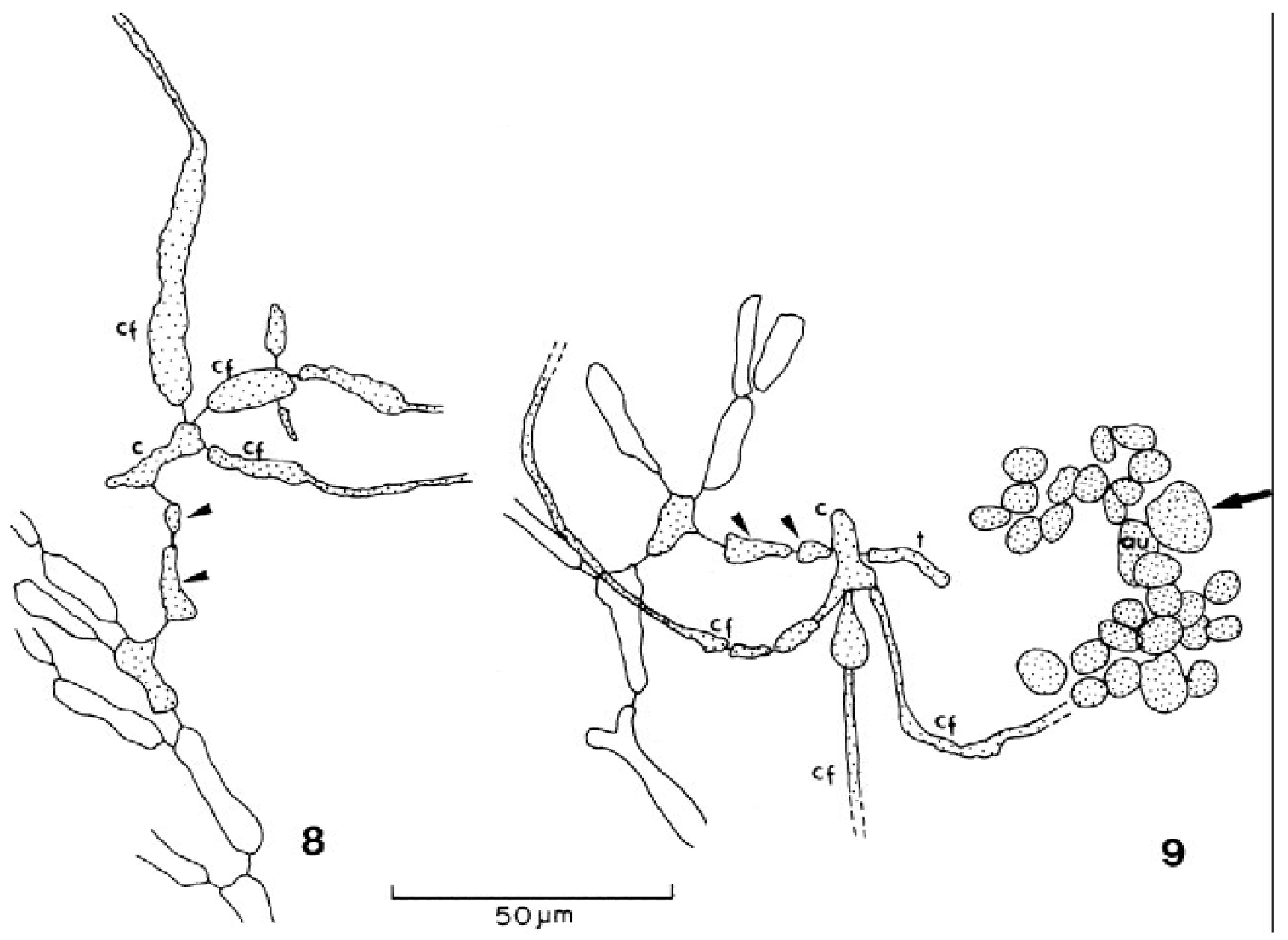

Figures 8-9. Predaea feldmannii. 8. A carpogonium (c) that has cut off three connecting filaments (cf). The arrowheads show the first and second cells of the carpogonial branch. 9. A carpogonium (c) that has cut off three connecting filaments (cf). A connecting filament has fused laterally to an auxiliary cell (au) and has produced a bulge (arrow) from which the primary gonimoblast cell will be cut off. Arrowheads show the first and second cells of the carpogonial branch. The remains of the trichogyne (t) can be seen. 
Feldmann. Doubts concerning the conspecificity of P. pusilla and P. weldii (Kraft \& Abbott 1971, Kraft 1984, Millar \& Guiry 1989) were clarified by Verlaque (1990), who established the main diagnostic features separating these two species.

From the southwestern Atlantic, Howe \& Taylor (1931) described a new species of Platoma, Platoma tenue M. Howe \& W.R. Taylor from Rio de Janeiro, Brazil, but this species has been considered conspecific with Predaea masonii (Setch. \& N.L. Gard.) G. De Toni (Fan in Dawson 1961). However, Bula Meyer (1992) reported that Platoma tenue and Predaea masonii were not the same and proposed that the western Atlantic records of Predaea masonii should be referred to Predaea tenuis (M. Howe \& W.R. Taylor) Bula-Meyer. Kajimura (1995) questioned Bula Meyer's identification establishing that the later species clearly corresponds to Predaea feldmannii. In addition, that proposed binomial was not validated by Bula-Meyer (1992), since he failed to provide a complete citation of the basionym. As commented by Kraft (1984), Predaea masonii is one of the poorest known species in the genus and is in great need of an accurate redescription based on new collections from its type locality. The same procedure can be applied to Platoma tenue M. Howe $\&$ W.R. Taylor. Moreover, the relation of this latter species to Predaea feldmannii remains uncertain until a detailed study of Howe \& Taylor's type material be done.

The bulk of morphological characteristics presented by the Brazilian specimens of Espírito Santo State clearly allows its placement in Predaea feldmannii, according to the diagnostic features presented by Millar \& Guiry (1989), Verlaque (1990), and Kajimura (1995), namely: gonimoblast initial formed on a bulge of the connecting filament, cortical filaments of nearly equal lengths, lack of glands cells, dense clusters of nutritive cells borne only on cells immediatelly contiguous to auxiliary cells and carpogonial branch three-celled.

The female reproductive structures and postfertilization events also agree with the data presented by Kraft \& John (1976) for Predaea feldmannii from Ghana. Børgesen (1950), Kraft \& John (1976), and Schneider \& Searles (1991) described dioecious plants for $P$. feldmannii, but we find them to be monoecious.
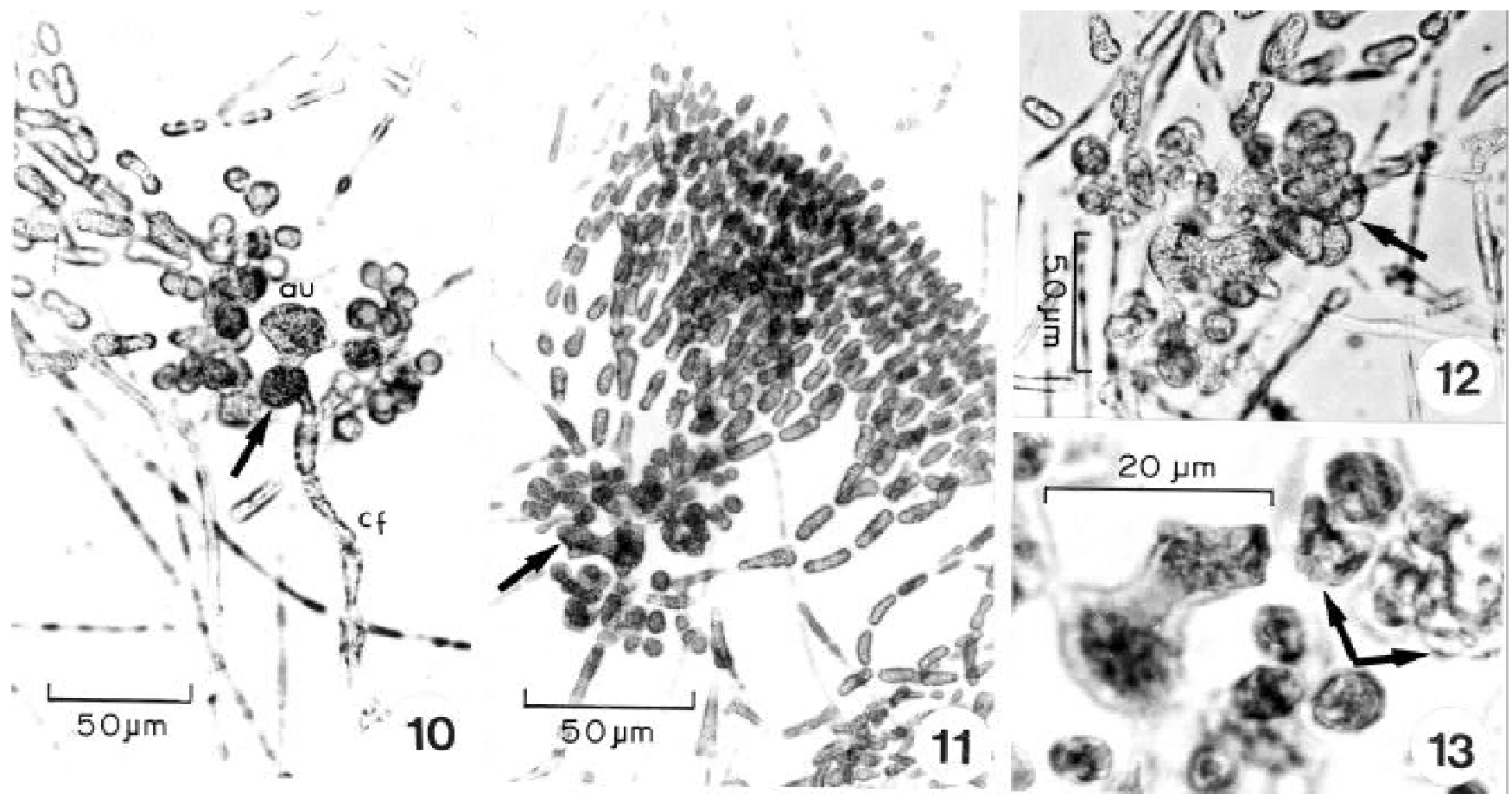

Figures 10-13. Predaea feldmannii. 10. After fusing with an auxiliary cell (au), a connecting filament (cf) produced a prominent lateral bulge (arrow) from which the primary gonimoblast cell will be cut off. 11 . Aspect of the auxiliary cell branch after presumed fertilization with the prominent lateral bulge (arrow) before the cutting of the gonimoblast cells. 12-13. Tight clump of early gonimoblast cells (arrows) cut laterally from the bulge. 


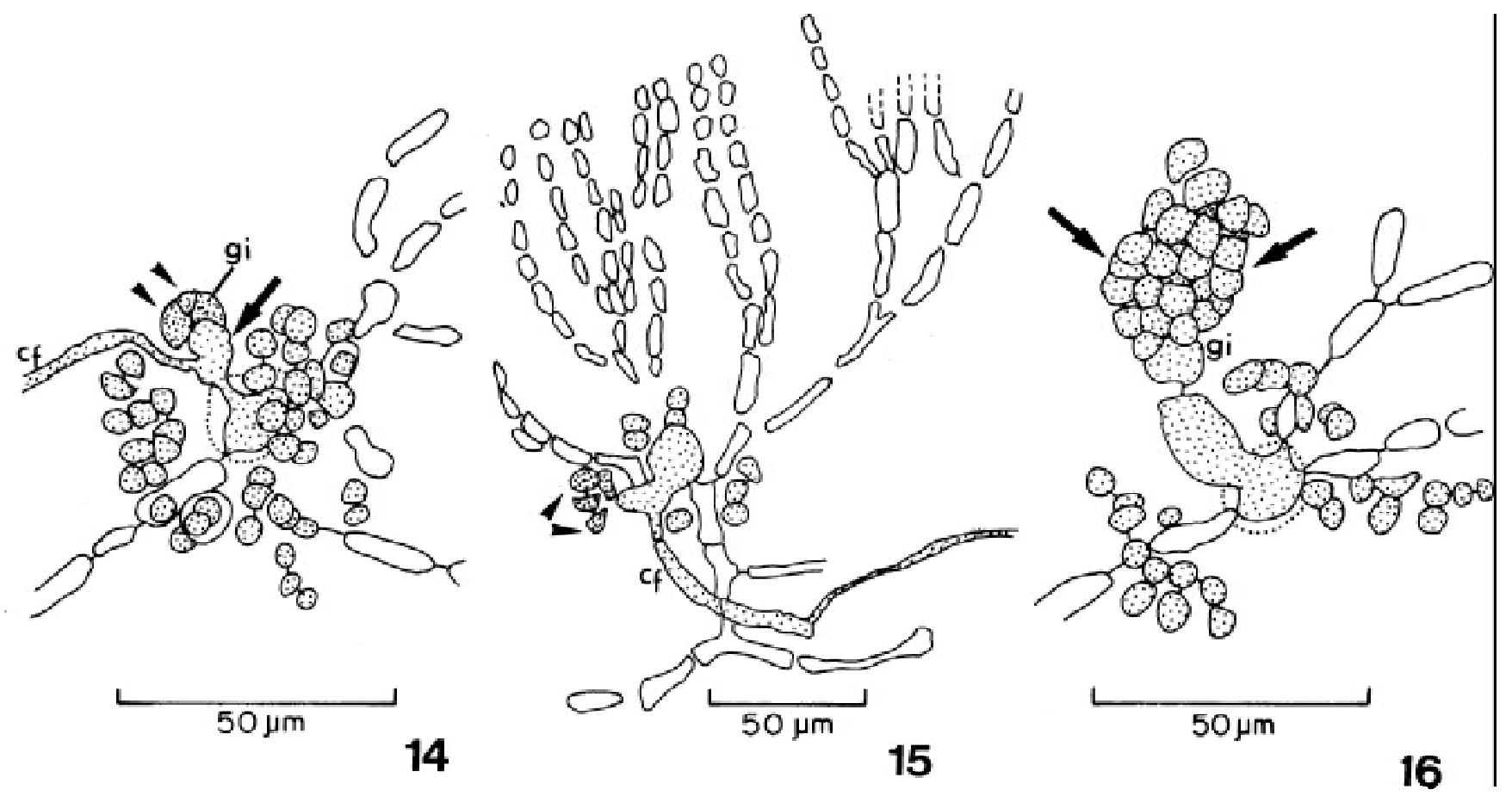

Figures 14-16. Predaea feldmannii. 14. Early gonimoblast cells (arrowheads) derived from the bulge (arrow) of the connecting filament (cf); gi = gonimoblast initial. 15. The gonimoblast initial divides and its derivatives form a chain (arrowheads) composed of cells laterally directed or arched; $\mathrm{cf}=$ connecting filament. 16. Further development of the carposporophyte with gonimoblast initial (gi) and a mass of carposporangia (arrows).

The monoecious versus the dioecious condition does not represent a diagnostic feature in Predaea, as for example, in P. laciniosa (Kraft 1984), and in P. kuroshioensis Kajimura (Kajimura 1995), monoecious and dioecious specimens occur in the same collection. According to Kraft (1984) in some species of Predaea it may be that the male and female gametangia are produced sequentially and that the sparsely scattered spermatangial clusters, as we found in P. feldmannii, probably represent spermatangial remnants on a cystocarpic thallus.

Acknowledgements - This study was partially supported by the Brazilian Research Council - CNPq (proc. 520748/97-2 and 304953/2003-2).

\section{References}

BALLANTINE, D.L. \& APONTE, N.E. 1997. Notes on the benthic marine algae of Puerto Rico. VI. Additions to the flora. Botanica Marina 40:39-44.

BALLANTINE, D.L. \& WYNNE, M.J. 1986. Notes on the marine algae of Puerto Rico. I. Additions to the flora. Botanica Marina 29:131-135.

BALLANTINE, D.L., RUIZ, H. \&APONTE, N.E. 2002. Predaea goffiana sp. nov., (Nemastomataceae, Rhodophyta) from Puerto Rico, Caribbean Sea. Botanica Marina 45:385-389.
BØRGESEN, F. 1950. A new species of the genus Predaea. Dansk Botanisk Arkiv 14:1-8.

BULA-MEYER, G. 1992. Is Platoma tenuis (Gigartinales, Rhodophyta) from the Atlantic really conspecific with Predaea masonii from the Mexican Pacific? In Anales del II Congreso Latinoamericano de Ficologia Marina (J.A. Acosta, ed.). Revista de la Facultad de Oceanografia, Pesquería y Ciencias Alimentarias, Universidad Nacional Federico Villareal 2:61-71.

CORDEIRO-MARINO, M. \& GUIMARÃES, S.M.P.B. 1981. Novas referências para a flora marinha de profundidade do Brasil. Rickia 9:61-70.

DAWSON, E.Y. 1961. Marine red algae of Pacific Mexico, part 4. Gigartinales. Pacific Naturalist 2:191-343.

GUIMARÃES, S.M.P.B. 2003. Uma análise da diversidade da flora marinha bentônica do Estado do Espírito Santo, Brasil. Hoehnea 30:11-19.

HORTA, P.A. \& OLIVEIRA, E.C. 2000. Morphology and reproduction of Anotrichium yagii (Ceramiales, Rhodophyta) - a new invader seaweed in the American Atlantic? Phycologia 39:390-394.

HORTA, P.A. \& OLIVEIRA, E.C. 2001. Some Delesseriaceae (Ceramiales, Rhodophyta) new to the southwestern Atlantic. Revista Brasileira de Botânica 24:447-454.

HORTA, P.A.,AMANCIO, E., COIMBRA, C.S. \& OLIVEIRA, E.C. 2001. Considerações sobre a distribuição e origem da flora de macroalgas marinhas brasileiras. Hoehnea 28:243-265. 
HOWE, M.A. \& TAYLOR, W.R. 1931. Notes on new or little known marine algae from Brazil. Brittonia 1:7-33.

JOLY, A.B. 1950. Resultados científicos do cruzeiro do "Baependi" e do "Vega" à Ilha da Trindade. Nota preliminar sobre algumas algas. Boletim do Instituto Paulista de Oceanografia 1:73-75.

JOLY, A.B \& OLIVEIRA, E.C. 1967. Two Brazilian Laminarias. Publicação 4. Instituto de Pesquisas da Marinha, Rio de Janeiro.

JOLY, A.B. \& YONESHIGUE-BRAGA, Y. 1966. Primeira nota sobre algas coletadas durante as viagens do navio oceanográfico "Almirante Saldanha". Nota Técnica 34. Instituto de Pesquisas da Marinha, Rio de Janeiro.

KAJIMURA, M. 1995. Predaea kuroshioensis sp. nov. (Nemastomataceae, Rhodophyta) from Japan. Phycologia 34:293-298.

KRAFT, G.W. 1984. The red algal genus Predaea (Nemastomataceae, Gigartinales) in Australia. Phycologia 23:3-20.

KRAFT, G.W. \& ABBOTT, I.A. 1971. Predaea weldii, a new species of Rhodophyta from Hawaii, with an evaliation of the genus. Journal of Phycology 7:194-202.

KRAFT, G.W. \& JOHN, D.M. 1976. The morphology and ecology of Nemastoma and Predaea species (Nemastomataceae, Rhodophyta) from Ghana. British Phycological Journal 11:331-344.
LEMUS, A.J. \& GANESAN, E.K. 1977. Morphological and culture studies in two species of Predaea G. De Tony (Rhodophyta, Gymnophloeaceae) from the Caribbean Sea. Boletin do Instituto Oceanográfico, Universidad de Oriente 16:63-77.

MILLAR, A.J.K. \& GUIRY, M.D. 1989. Morphology and life history of Predaea kraftiana sp. nov. (Gymnophloeaceae, Rhodophyta) from Australia. Phycologia 28:409-421.

OLIVEIRA, E.C. 1976. Deep water marine algae from Espírito Santo State (Brazil). Boletim de Botânica, Universidade de São Paulo 4:73-80.

OLIVEIRA, E.C. 1977. Algas marinhas bentônicas do Brasil. Tese de livre-docência, Universidade de São Paulo, São Paulo.

SAUNDERS, G.W. \& KRAFT, G.T. 2002. Two new Australian species of Predaea (Nemastomataceae, Rhodophyta) with taxonomic recommendations for an emended Nemastomatales and expanded Halymeniales. Journal of Phycology 28:1245-1260.

SCHNEIDER, C.W. \& SEARLES, R.B. 1975. North Carolina marine algae. IV. Further contributions from the continental shelf, including two new species of Rhodophyta. Nova Hedwigia 26:83-103.

SCHNEIDER, C.W. \& SEARLES, R.B. 1991. Seaweeds of the southeastern United States. Cape Hatteras to Cape Canaveral. Duke University Press, Durham.

VERLAQUE, M. 1990. Contribution à l'étude du genre Predaea (Rhodophyta) en Méditerranée. Phycologia 29:489-500. 
